\title{
Mallomonas minuscula sp. nov. (Synurales, Chrysophyceae), a new member in the section Torquatae from Vietnam
}

\author{
Evgeniy Gusev $^{1,2 *}$, Elena Guseva ${ }^{1}$, Elena Kezlya ${ }^{1} \&$ Maxim KulikovskiY $^{1}$
}

\author{
${ }^{1}$ K.A. Timiryazev Institute of Plant Physiology, Russian Academy of Sciences, Botanical Street 35, 127276, \\ Moscow, Russia; *Corresponding authore-mail:evsergus@yahoo.com \\ ${ }^{2}$ Joint Russian-Vietnamese Tropical Research and Technological Center, Nguen Van Huen Street 63, Hanoi, \\ Vietnam
}

\begin{abstract}
Mallomonas minuscula sp. nov. is described from Vietnam based on silica-scale morphology studied by means of transmission and scanning electron microscopy. This species belongs to the Mallomonas mangofera complex and is characterized by small scales with large polygonal papillae on the shield, raised wide arms on the anterior submarginal rib with small papillae, and a small "window" in the angle of the posterior submarginal rib. Scales of Mallomonas minuscula were found in nine localities from six provinces of Central and Southern Vietnam. The distributions and habitat conditions of the new species are summarized.
\end{abstract}

Key words: Synurales, Mallomonas minuscula, Torquatae, scale ultrastructure, new species, Vietnam

\section{INTRODUCTION}

Mallomonas is the most diverse genus in Order Synurales (Stramenopiles, Chrysophyceae). Species of this genus are widely distributed in various freshwater habitats from cold areas to tropics (KRISTIANSEN 2000; KRISTIANSEN \& PreISIG 2007) with some species found in saline waters (GuSEv 2013; NĚMCoví et al. 2016). Cells of Mallomonas are covered with siliceous scales and bristles, which are specific for each taxon. According to the most recent multigene phylogeny of synuralean algae (SIVER et al. 2015), Mallomonas is divided into two large major lineages, one comprised of scales that possess a V-rib and the other lacks this structure. Intensive studies of the last decade with molecular and morphological approaches show that the real diversity of the genus is underestimated. Over last ten years, twenty new Mallomonas species have been described from different regions in Asia, including one from Russia (Gusev \& KULIKOvSKIY 2013), two from China (MA \& WeI 2013; NĚMCová et al. 2015), six from Korea (KIm \& KIM 2008; KIm \& Kiм 2010; Jo et al. 2013; KIм et al. 2014), and eleven from Vietnam (Gusev 2012, 2013, 2015a,b; GusEv et al. 2015, 2016, 2017, 2018; GUSEV \& SivER 2017). Two of these, Mallomonas elevata Han Soon Kim and Mallomonas jejuensis Han Soon Kim et Jin Hee Kim, belong to the Mallomonas mangofera group in the section Torquatae, series Mangoferae. This group also includes M. mangofera K. Harris et D.E. Bradley, M. mangofera var. foveata (Dürrschmidt) Kristiansen, M. mangofera var. gracilis (Dürrschmidt) Kristiansen, M. mangofera var. sulcata Dürrschmidt, M. mangofera var. reticulata (Cronberg) Kristiansen, M. alveolata Dürrschmidt, and M. liturata K.H. Nicholls. It should be mentioned that the series Mangoferae is probably an artificial group that combined species with the papillae on the shield of the scales and with increasing availability of molecular data it can be revised.

The aim of this paper is to describe a new species from the Mallomonas mangofera group, Mallomonas minuscula sp. nov.

\section{Material ANd Methods}

Samples from nine localities in six provinces in Vietnam are included in this study (Fig. 1, Table 1). In Khanh Hoa Province samples were collected from an unnamed sand pit with standing water situated on the Cam Ranh Peninsula in 2012. In Lam Dong Province samples were collected from Da Kha Reservior in 2012. Two 2015 samples were taken in the northwestern part of Phu Quoc Island (Kien Giang Province) from unnamed ponds. A sample from Con Son Island, Ba Rịa-Vung Tau Province, was taken from a small pond near Quang Trung Reservoir in 2015. In Phu Yen and Binh Dinh Provinces, samples were collected from lakes and reservoirs in 2018.

Samples were collected using a plankton net with 20 $\mu \mathrm{m}$ mesh. For electron microscopy studies, an aliquot of each sample was washed three times by repeated centrifugation 
Table 1. Ecological conditions and distributional records for Mallomonas minuscula.

\begin{tabular}{|c|c|c|c|c|}
\hline Site & Coordinates & $\mathrm{pH}$ & $\begin{array}{l}\text { Spec Cond } \\
\left(\mu \mathrm{S} . \mathrm{cm}^{-1}\right)\end{array}$ & $\begin{array}{l}\text { Temperature } \\
\left({ }^{\circ} \mathrm{C}\right)\end{array}$ \\
\hline 1. Sandpit in Cam Ranh Peninsula, Khanh Hoa Province & $\begin{array}{l}12^{\circ} 04^{\prime} 43^{\prime \prime} \mathrm{N} \\
109^{\circ} 11^{\prime} 26^{\prime \prime} \mathrm{E}\end{array}$ & 6.1 & 36 & 34 \\
\hline 2. Pond (Con Son Island), Baria-Vung Tau Province & $\begin{array}{l}8^{\circ} 41^{\prime} 32^{\prime \prime N} \\
106^{\circ} 36^{\prime} 22^{\prime \prime} \mathrm{E}\end{array}$ & na & na & na \\
\hline 3. Unnamed pond 1, Phu Quoc Island, Kien Giang Province & $\begin{array}{l}10^{\circ} 19^{\prime} 51 " \mathrm{~N} \\
103^{\circ} 51^{\prime} 32^{\prime \prime} \mathrm{E}\end{array}$ & 6.0 & 117 & 33 \\
\hline 4. Unnamed pond 2, Phu Quoc Island, Kien Giang Province & $\begin{array}{l}10^{\circ} 19^{\prime} 50^{\prime \prime} \mathrm{N} \\
103^{\circ} 51^{\prime} 32^{\prime \prime} \mathrm{E}\end{array}$ & 6.3 & 186 & 32 \\
\hline 5. Da Kha Reservior, Lam Dong Province & $\begin{array}{l}12^{\circ} 06^{\prime} 36^{\prime \prime} \mathrm{N} \\
108^{\circ} 34^{\prime} 51^{\prime \prime} \mathrm{E}\end{array}$ & 6.8 & 23 & 22 \\
\hline 6. Lake Dam Tra O, Binh Dinh Province & $\begin{array}{l}14^{\circ} 19^{\prime} 28^{\prime \prime} \mathrm{N} \\
109^{\circ} 07^{\prime} 38^{\prime \prime} \mathrm{E}\end{array}$ & 6.1 & 247 & 34 \\
\hline 7. Lake Bau Ba, Binh Dinh Province & $\begin{array}{l}14^{\circ} 29^{\prime} 20^{\prime \prime} \mathrm{N} \\
109^{\circ} 01^{\prime} 27^{\prime \prime} \mathrm{E}\end{array}$ & 6.3 & 91 & 36 \\
\hline 8. Unnamed reservoir, Binh Dinh Province & $\begin{array}{l}14^{\circ} 30^{\prime} 04^{\prime \prime} \mathrm{N} \\
109^{\circ} 01^{\prime} 11^{\prime \prime} \mathrm{E}\end{array}$ & 6.5 & 109 & 34 \\
\hline 9. Hao Son Reservoir, Phu Yen Province & $\begin{array}{l}12^{\circ} 53^{\prime} 51^{\prime \prime N} \\
109^{\circ} 23^{\prime} 04^{\prime \prime} \mathrm{E}\end{array}$ & 6.4 & 119 & 30 \\
\hline
\end{tabular}

with deionized water. Drops of each washed sample were dried directly onto stubs for Scanning Electron Microscope (SEM) or grids for Transmission Electron Microscope (TEM) or digested 4-5 minutes in sulfuric acid with potassium dichromate before mounting. For SEM studies, samples were dried onto aluminum stubs, coated with gold for 10 minutes with a JEE-4X (JEOL) sputter coater, and observed with a JEOL 6510 LV scanning electron microscope. For TEM studies, samples were dried onto formvar coated grids (EMS FF200 $\mathrm{Cu}-50$, Electron Microscopy Sciences), and observed with a JEM-1011 TEM. Specific conductance, $\mathrm{pH}$ and temperature measurements were made with a Hanna HI 9828 device, Hanna Instruments, Inc., USA.

\section{RESULTS}

Mallomonas minuscula sp. nov. Gusev, Guseva, Kezlya et Kulikovskiy

Description: Cells are ellipsoidal, size of dried cells approximately $9-12 \times 4-5 \mu \mathrm{m}$. Cells armored with apical domed collar scales, domeless body scales, and small rear scales with short spines. The body scales are rhomboidal and slightly asymmetric, $2.0-2.5 \times 1.3-1.7$ $\mu \mathrm{m}$. Shield is ornamented with numerous evenly spaced large polygonal papillae and small pores on base plate. Anterior submarginal rib is well developed, raised above the shield, wide, with 1 to 3 rows of delicate papillae on each arm. Anterior flanges are smooth. Posterior submarginal rib is smooth and fused with the arms of the anterior submarginal rib. There is a rounded area in the angle of the posterior submarginal rib, lacking secondary layer ("window"). "Window" contains one pore on the base plate. Posterior border is smooth and encircles half of the scale. Posterior flange is narrow and smooth. The rear scales are similar in structure to the body scales, but more oval and asymmetric, bearing small spines and smaller size, $1.5-1.7 \times 1.1-1.4 \mu \mathrm{m}$. The collar scales are asymmetrical, elongate, and have a broadly rounded proximal end and narrower distal end, 2.4-2.8 $\times 1.4-2.0 \mu \mathrm{m}$. Ornamentation on the shield, submarginal ribs and flanges is the same as found on the body scales. The dome on the collar scales is ornamented with papillae, and has a stout and sharply pointed peak at the apex. There are 2-5 base plate pores in the angle of the posterior submarginal rib. Bristles are short, 4-5 $\mu \mathrm{m}$ in length, curved, smooth and pointed. Cysts were not observed.

Holotype specimen: Portion of a single gathering of cells on SEM stub No. CR91 (holotype designated here in Fig. 5) deposited at the Herbarium, Papanin Institute for Biology of Inland Waters RAS, Borok (IBIW). Material from unnamed sandpit in Cam Ranh Peninsula, Khanh Hoa Province, Vietnam collected by E.S. Gusev on the $25^{\text {th }}$ of June, 2012. Figure 5 is a representative scale from the specimen.

Type Locality: Unnamed sandpit in Cam Ranh Peninsula, Khanh Hoa Province, Vietnam. Latitude/Longitude: $12^{\circ}$ 04'43", N 109¹1'26"E.

Epithet: Epithet refers to small size of scales.

Distribution: In addition to the type locality, this species has been observed in other regions of Vietnam: Con Son Island, Phu Quoc Island, Da Kha Reservior in Lam Dong Province, Hao Son Reservoir in Phu Yen Province, Dam Tra O Lake, Bau Ba Lake and unnamed reservoir in Binh Dinh Province (Table 1). Mallomonas minuscula was found in slightly acidic conditions ( $\mathrm{pH}$ from 6.0 to 6.8 ) 


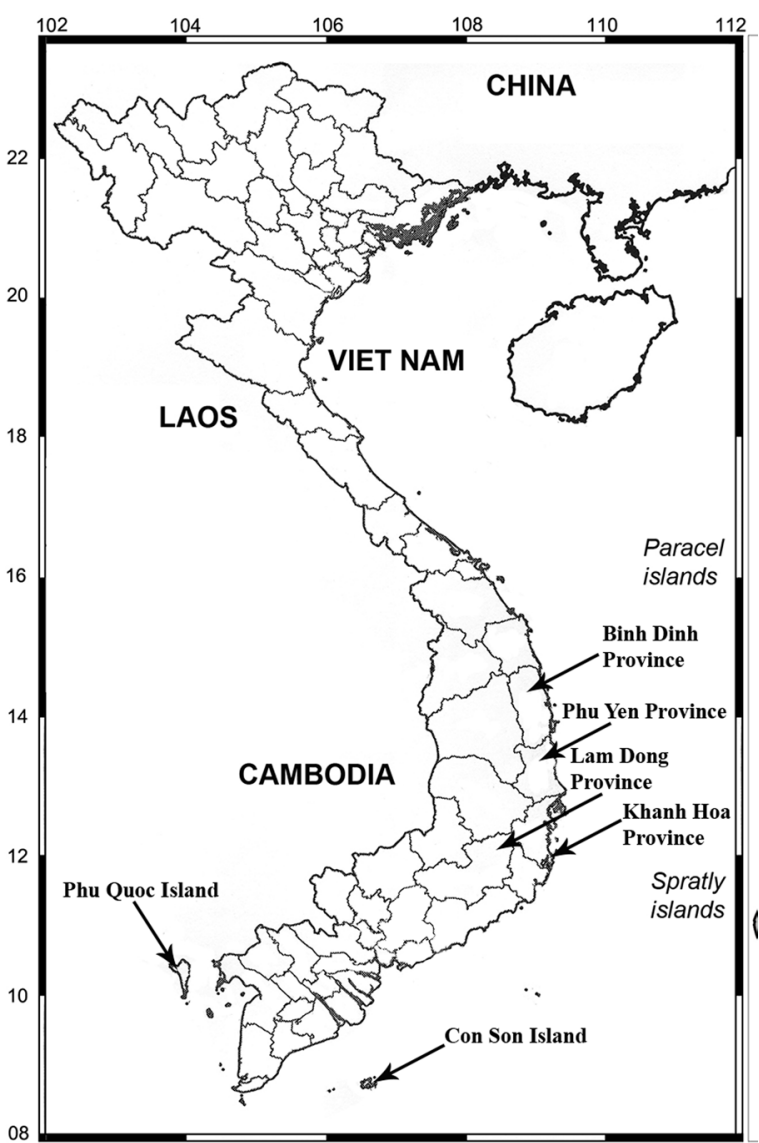

Fig. 1. Geographical position of the studied area.

with specific conductance range of 23 to $247 \mu \mathrm{S} . \mathrm{cm}^{-1}$, and temperature $22-36{ }^{\circ} \mathrm{C}$ (Table 1 ).

\section{Discussion}

Mallomonas minuscula should be placed in Section Torquatae Momeu \& Péterfi (Momeu \& PÉTERFi 1979) due to presence of domed collar scales. Within this large section, Mallomonas minuscula is similar to species from the M. mangofera group which also have papillae on the scales. The main distinctive feature of the newly described species is the large polygonal, often hexagonal, papillae on the shield organized in regular pattern and not fused together. Polygonal or hexagonal form of large papillae is easily observed with TEM, but not as obvious with SEM. Raised wide arms of the anterior submarginal rib, ornamented with small papillae arranged in rows, and small "window" with one pore in the angle of the posterior submarginal rib are also characteristic features of Mallomonas minuscula. New taxon is similar to Mallomonas madagascariensis Hansen, M. crocidilorum Hansen, described from Madagascar (HANSEN \& Kristiansen 1995) and M. liturata, described from Canada (Nichols 1988). All these species have large papillae on the shield. Mallomonas minuscula and $M$. madagascariensis have small rhomboidal body scales with broad anterior ribs and shield bearing large polygonal papillae (flat-topped tubercles), arranged in a regular hexagonal way. The main discriminant feature between two taxa is the shield pattern of papillae. Mallomonas madagascariensis has numerous confluences of papillae building a pattern of shorter labyrinthic corridors on the shield. Mallomonas minuscula has regular pattern of papillae on the shield and confluences has never been observed. Also Mallomonas madagascariensis has 3-4 pores in a "window" while $M$. minuscula has only one. Mallomonas crocodilorum, unlike $M$. minuscula, have larger body scales $(2.7-4.0 \times 1.6-3.0 \mu \mathrm{m})$ with shield pattern consisting of irregular papillae arranged with no consistent symmetry and with two rows of shield papillae continue into one side of the anterior flange. The body scales of Mallomonas liturata are larger, 2.8-4.7 $\times 1.8-3.3 \mu \mathrm{m}$ than the $2.0-2.5 \times 1.3-1.7 \mu \mathrm{m}$ of $M$. minuscula. Papillae on the scales of Mallomonas liturata are rounded, large base plate pores are positioned in the space between each group of four papillae. Papillae on the shield of the scales of Mallomonas minuscula are usually hexagonal in form, small base plate pores are scarcely distributed on the shield. Mallomonas minuscula also resembles Mallomonas elevata Han Soon Kim, described from South Korea (KIM et al. 2014). Both taxa have a wide submarginal anterior rib raised above the shield and ornamented with papillae. These taxa differ by the shield ornamentation and scale sizes. Scales of Mallomonas elevata are larger (body scales are 3.7-4.5 × 2.7-3.1 $\mu \mathrm{m}$ ) and have regular rows of evenly spaced small papillae on the shield. Scales of Mallomonas minuscula are ornamented with numerous evenly spaced papillae of hexagonal form, contain small pores on the base plate and have the "window". The "window" and small scales $(2.2 \times 1.6 \mu \mathrm{m})$ were reported also for Mallomonas mangofera $\mathrm{f}$. gracilis Dürrschmidt, described from Chile (DüRRSCHMIDT 1983). This taxon clearly differs from Mallomonas minuscula in that the papillate pattern is weakly developed, papillae are smaller and more numerous, apparently fused together to a continuous secondary layer on the shield for some scales. Other varieties of Mallomonas mangofera and $M$. alveolata differ from $M$. minuscula by the larger scale sizes, narrower anterior ribs and shield ornamentation.

Newly described species was quite rare in the samples, but widely distributed in Vietnam. Scales of Mallomonas minuscula were found in nine localities from six provinces in Central and Southern parts of Vietnam. Based on these findings we expect a wider distribution of this species in Southeast Asia. Mallomonas minuscula prefers slightly acidic waters ( $\mathrm{pH}$ from 6.0 to 6.8 ), low specific conductance values $\left(23-247 \mu \mathrm{S} . \mathrm{cm}^{-1}\right)$ and can tolerate a wide range of temperature $\left(22-36^{\circ} \mathrm{C}\right)$.

\section{ACKNOWLEDGEMENTS}

Authors are grateful to the staff of the Centre of Electron Microscopy of the Papanin's Institute for Biology of Inland Waters, RAS, for technical assistance, D. Kapustin for preparing some SEM images, 

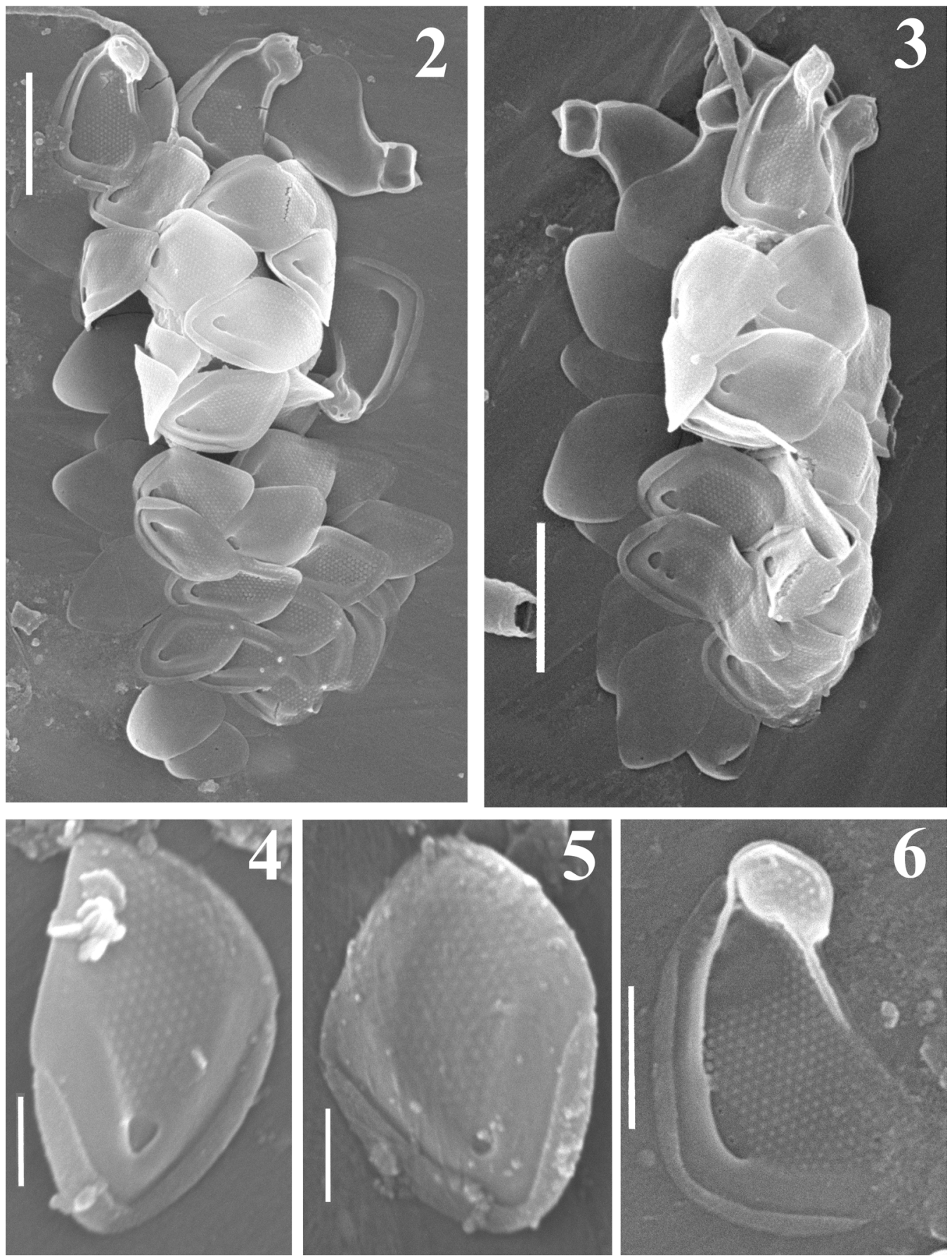

Figs 2-6. Mallomonas minuscula sp. nov., SEM images of different types of scales: (2-3) Group of scales (whole dried cells), Phu Quoc Island; (4-5) Body scales, Cam Ranh Peninsula; (6) Collar scale, Phu Quoc Island. Scale bars $2 \mu \mathrm{m}$ (Figs 2-3), $1 \mu \mathrm{m}$ (Fig. 6), $0.5 \mu \mathrm{m}$ (Figs 4-5).

Tran Duc Dien and Phan Trong Huan for help in expeditions. This work was funded by the Russian-Vietnam Tropical Centre, Ecolan 3.2 theme. Authors are grateful to Professor Kevin McCartney for English correction and important remarks. Authors are grateful to anonymous reviewer for helpful comments that improved the quality of the manuscript.

\section{REFERENCES}

DüRRSCHMIDT, M. (1983): A taxonomic study of the Mallomonas mangofera group (Mallomonadaceae, Chrysophyceae), including the description of four new taxa. - Plant
Systematics and Evolution 143: 175-196.

Gusev, E.S. (2012): A new species of the genus Mallomonas (Synurophyceae), Mallomonas spinosa sp. nov., from Vietnam. - Phytotaxa 66: 1-5.

GuSEv, E.S. (2013): Studies on synurophycean algae from mangrove wetlands (Vietnam). - Nova Hedwigia Beiheft 142: 87-95.

Gusev, E.S. (2015a): A new species of the genus Mallomonas (Synurales, Chrysophyceae), Mallomonas fimbriata sp. nov. - Phytotaxa 195: 291-296.

Gusev, E.S. (2015b): A New Species in Genus Mallomonas Perty (Synurales, Chrysophyceae) from Vietnam. 

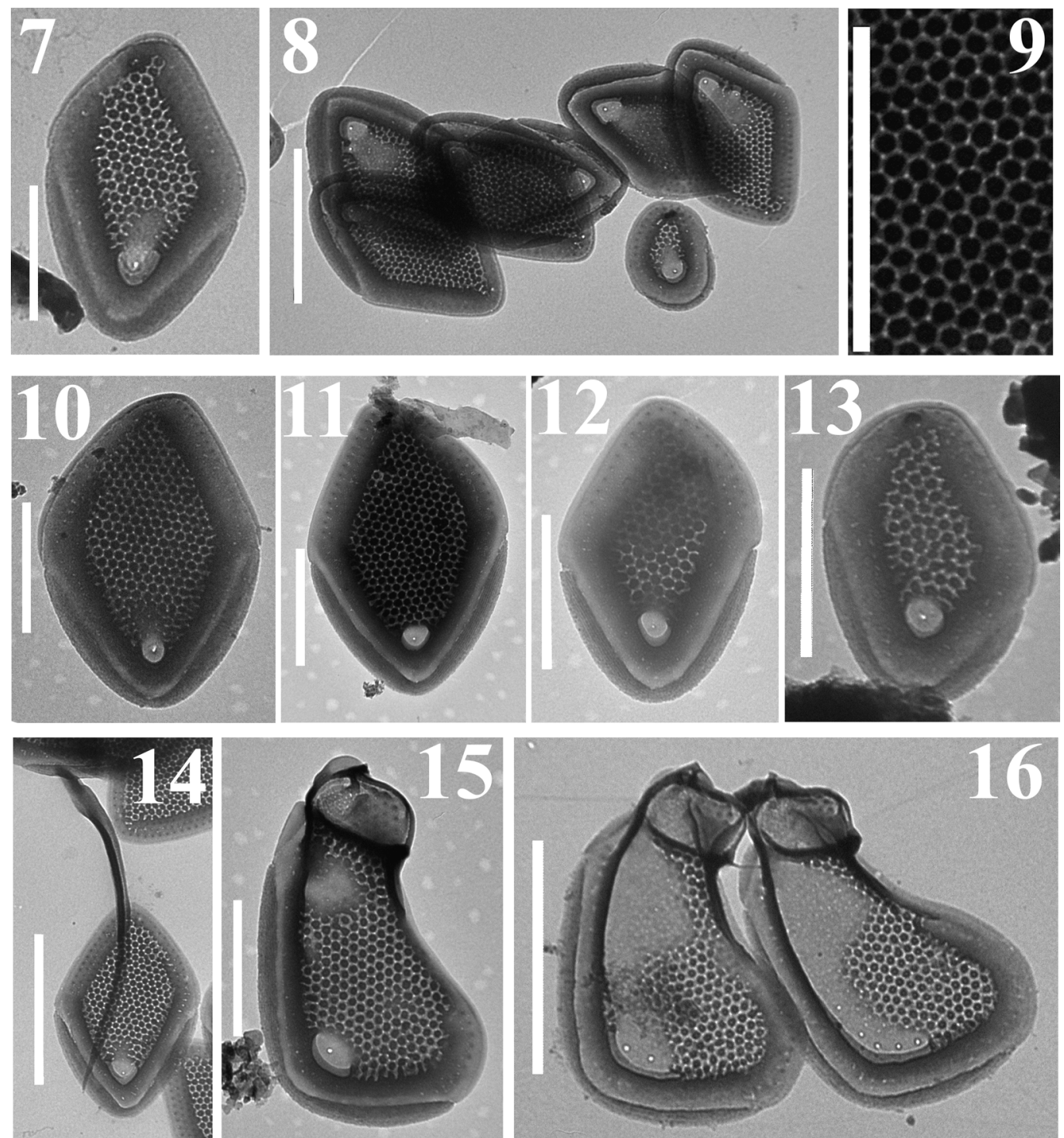

Figs 7-16. Mallomonas minuscula sp. nov., TEM images of different types of scales: (7) Body scale, Phu Quoc Island; (8) Group of body scales and a rounded caudal scale, Phu Quoc Island; (9) Shield pattern with polygonal papillae; (10-12) Body scales, Cam Ranh Peninsula; (13) Caudal scale, Cam Ranh Peninsula; (14) Bristle, Phu Quoc Island; (15) Collar scale, Cam Ranh Peninsula; (16) Two collar scales, Phu Quoc Island. Scale bars: $2 \mu \mathrm{m}$ (Figs 8, 14, 16), $1 \mu \mathrm{m}$ (Figs. 7, 9, 10-13, 15).

- International Journal on Algae 17: 351-362.

Gusev, E.S. \& KulikovskiY, M.S. (2013): A new species of the genus Mallomonas (Chrysophyceae: Synurales), Mallomonas kuzminii sp. nov., from lake Frolikha (Russia, Baikal region). - Phytotaxa 155: 66-70.

Gusev, E.S.; DoAn-Nhu, H. \& NGuyen-NGoc, L. (2015): Mallomonas cattiensis, sp. nov. (Synurales, Chrysophyceae), a new species from Viet Nam. - Phytotaxa 221: 188-192.

Gusev, E.S.; DoAN-Nhu, H.; NGUYeN-NGOC, L. \& Kapustin, D.A. (2016): Two new species of the genus Mallomonas from the Cat Tien National Park (Viet Nam): Mallomonas distinguenda and Mallomonas skvortsovii. - Phytotaxa 273: 59-64.

Gusev, E.S. \& Siver, P.A. (2017): Mallomonas neoampla sp. nov. from Vietnam, a new species that bridges the gap between fossil and modern taxa. - Nova Hedwigia 104: 521-528.

Gusev, E.S.; Siver, P.A. \& SHIN, W. (2017): Mallomonas bronchartiana Compère revisited: Two new species described from Asia. - Cryptogamie, Algologie 38: 3-16. Gusev, E.; Čertnerová, D.; ŠKaloudová, M. \& ŠKaloud, P. (2018): Exploring cryptic diversity and distribution patterns in the Mallomonas kalinae/rasilis species complex with a description of a new taxon. Mallomonas furtiva sp. nov. - Journal of Eukaryotic Microbiology 65: 38-47.

Hansen, P. \& KRISTIANSEn, J. (1995): Mallomonas madagascariensis, M. lemuriocellata and M. crocodilorum (Synurophyceae), three new species from Madagascar. - Nordic Journal of Botany 15: 215-223.

Jo, B. Y.; Shin, W.; Kim, H. S.; Siver, P. A. \& ANDERSEN, R. A. (2013): Phylogeny of the genus Mallomonas (Synurophyceae) and descriptions of five new species on the basis of morphological evidence. - Phycologia 52: $266-278$

KIM, H.S. \& KIM, J.H. (2008); Mallomonas koreana sp. nov. (Synurophyceae), a new species from South Korea.Nova Hedwigia 86: 469-476. 
KIM, J.H. \& KIM, H.S. (2010); Mallomonas jejuensis sp. nov. (Synurophyceae) from Jeju Island, South Korea. Nordic Journal of Botany 28: 350-353.

Kıм, H.S.; Kıм, J.H.; SHIN, W. \& Jo, B.Y. (2014): Mallomonas elevata sp. nov. (Synurophyceae), a new scaled Chrysophyte from Jeju Island, South Korea. - Nova Hedwigia 98: 89-102.

KristianSEN, J. (2000): Cosmopolitan chrysophytes. - Systematics and Geography of Plants 70: 291-300.

Kristiansen, J. \& Preisig, H.R. (2007): Chrysophyta and Haptophyta Algae, 2nd part: Synurophyceae. - In: BüDel, B., G. Gärtner, L. Krienitz, H.R. Preisig \& M. SchaGerL (eds): Süsswasserflora von Mitteleuropa (Freshwater flora of Central Europe), vol. 1/2 - pp. 1-252, Spektrum Akademisher Verlag, SpringerVerlag, Berlin.

MA C.X. \& Wei Y.X. (2013): A new species of the genus Mallomonas found in the national wetland preserve in Zhenbaodao, Heilongjiang, northeast China. - Nova Hedwigia 96: 457-462.

Momeu, L. \& PÉTERFI, L.S. (1979): Taxonomy of Mallomonas based on the fine structure of the scales and bristles. - Contribuţii Botanice Cluj-Napoca 1979: 13-20.
Nemcová, Y.; Pichrtová, M. \& ZeISEK, V. (2015): Mallomonas alpestrina sp. nov. (Synurales, Chrysophyceae, Stramenopiles) and its spineless relatives - Mallomonas alata group. - Phytotaxa 222: 111-120.

NĚmcová, Y.; Pusztai, M.; ŠKaloudová, M. \& Neustupa, J. (2016): Silica-scaled chrysophytes (Stramenopiles, Ochrophyta) along a salinity gradient: a case study from the Gulf of Bothnia western shore (northern Europe). - Hydrobiologia 764: 187-197.

NicholLs, K.H. (1988): Descriptions of three new species of Mallomonas (Chrysophyceae): M. hexagonis, $M$. liturata and M. galeiformis. - British Phycological Journal 23:159-166.

Siver, P.A.; Jo, B.Y.; Kim, J.I.; Shin, W.; LotT, A.M. \& Wolfe, A.P. (2015): Assessing the evolutionary history of the class Synurophyceae (Heterokonta) using molecular, morphometric, and paleobiological approaches. American Journal of Botany 102: 921-941.

(C) Czech Phycological Society (2019)

Received February 8, 2019

Accepted April 16, 2019 